ARTIKEL PENELITIAN

\title{
PERBEDAAN PENGARUH DIET TINGGI MINYAK SAWIT SEGAR DENGAN MINYAK JELANTAH TERHADAP LEMAK DAN TNF- a DARAH TIKUS
}

\author{
Susila Sastri \\ Kepala Bagian Biokimia Fakultas Kedokteran Universitas Andalas \\ E-mail : susila_sastri@yahoo.com
}

\begin{abstract}
Abstrak
Masyarakat akhir-akhir ini cenderung memilih minyak sawit sebagai bahan penggoreng, hal ini mungkin karena harganya lebih murah dan mudah didapat dibandingkan minyak lain. Pemakain MS oleh masyarakat biasanya untuk bahan penggoreng bahan makanan. Minyak sawit mengandung asam lemak jenuh dan asam lemak tidak jenuh yang hampir seimbang, asam lemak jenuh meningkatkan lemak darah dan asam lemak tidak jenuh dikatakan dapat menurunkan lemak darah. Asam lemak tidak jenuh disisi lain mudah dioksidasi dengan pemanasan. Penelitian ini bertujuan melihat perbedaan pengaruh diet tinggi minyak sawit segar dan jelantah minyak sawit terhadap lemak darah dan TNF- $\alpha$.

Sudah dilakukan pemberian diet tinggi minyak sawit (50\%) pada tikus Wistar selama 8 minggu secara adlibitum. Pengukuran kadar kolesterol total, HDL-kol dan trigliserida melalui serum darah dengan alat spectrophotometer dan pemeriksaan TNF- $\alpha$ darah dengan cara ELISA.

Hasil penelitian menunjukkan terdapat peninggian kadar lemak (trigliserida dan kolesterol total) dan TNF- $\alpha$ darah bermakna $(\mathrm{p}<0,05)$ pada tikus diet tinggi minyak sawit segar ataupun minyak jelantah bila dibandingkan dengan kontrol namun peninggian lemak dan TNF- $\alpha$ oleh minyak jelantah lebih tinggi bermakna bila dibandingkan dengan minyak sawit segar. Kadar kolesterol darah tikus DMS lebih rendah dari kelompok kontrol positif.

Kesimpulan; diet tinggi minyak sawit segar dan minyak jelantah pada tikus dapat meningkatkan kadar kolesterol total, trigliserida dan TNF- $\alpha$ secara bermakna dibandingkan kontrol, sedangkan peningkatan oleh minyak jelantah lebih tinggi bermakna dari minyak sawit segar.
\end{abstract}

Kata kunci : diet tinggi minyak sawit, lemak darah, $T N F-\alpha$

\section{Abstract}

Society these days tend to prefer palm oil as raw roaster, this is probably because the price is cheap and easily available than other oils. MS usage by the community generally to material food fryer. Palm oil contains saturated fatty acids and unsaturated fatty acids are nearly balanced, saturated fatty acids increase blood fats and unsaturated fatty acid is said to lower blood fats. Unsaturated fatty acids on the other hand easily oxidized by heating. This study aims to look at 
differences in the influence of a diet high in fresh palm oil and palm oil used cooking oil on blood lipid and TNF- $\alpha$. Already done giving a diet high in palm oil $(50 \%)$ in Wistar rats for 8 weeks in adlibitum. Measurement of total cholesterol, HDL-Chol and triglycerides through the blood serum with a spectrophotometer and checking blood TNF- $\alpha$ by ELISA. The results showed there were elevated levels of fats (triglycerides and total cholesterol) and blood TNF- $\alpha$ significantly ( $p$ $<0.05$ ) in mice a diet high in fresh palm oil or used cooking oil when compared with controls but the elevation of fat and TNF- $\alpha$ by used cooking oil significantly higher when compared with fresh palm oil. DMS rat blood cholesterol levels lower than the positive control group. Conclusion: a diet high in fresh palm oil and used cooking oil in rats can increase total cholesterol, triglycerides and TNF- $\alpha$ significantly compared to controls, whereas the used cooking oil increased by significantly higher than fresh palm oil.

Key words : high diet palm oil, blood lipid, TNF- $\alpha$ 


\section{Pendahuluan}

Sumber minyak goreng masyarakat akhir-akhir ini cenderung beralih dari minyak kelapa (MK) ke minyak (MS), jenis minyak yang banyak beredar dipasar adalah minyak sawit jenis palm oil. Hal ini mungkin disebabkan harga MS lebih murah dan mudah didapatkan dipasaran dibandingkan dengan MK. Minyak sawit terutama mengandung asam lemak tak jenuh tunggal atau asam lemak tak tejenuh (USFA) lebih kurang 50\% dan asam lemak jenuh atau saturated fatty acid (SFA) yaitu asam palmitat $44 \%$.

Komsumsi minyak sawit pada umumnya oleh masyarakat sebagai bahan penggoreng makanan dimana minyak sawit dipanaskan dan penggorengan sering dilakukan berulang kali. Keadaan ini akan merusak struktur USFA yang terkandung dalam minyak tersebut dimana USFA dirubah menjadi SFA atau senyawa trans fatty acid. ${ }^{(1,2)}$ Transfatty oleic acid meningkatkan kadar TG darah 2 sampai 3 kali. $^{(3)}$

Oleic acid merupakan asam lemak tak jenuh tunggal atau monounsaturated fatty acid (MUFA) yang terkandung dalam minyak sawit (MUFA) sebanyak 38,7\% dan linoleic acid (PUFA) 10,5\%. Linoleic acid (LA) merupakan salah satu asam lemak esensial yang perlu dikomsumsi karena tubuh manusia tidak bisa mensintesa dalam tubuh dari senyawa lain. LA dalam tubuh dimetabolisme diantaranya menjadi Arachidonic acid (AA). Pada membran sel AA terikat sebagai pospolipid dan dengan bantuan phospholipase A2 dirubah menjadi senyawa eicosanoid yang bersifat proinflamasi seperti prostaglandin (PGE2 dan PGF2a).

Linoleic acid dapat menghambat proses glikolisis melalui enzim liver-type pyruvat kinase (LPK) sehingga pada sel hepar hasil glikolisis bukan piruvat tetapi senyawa sampingan berupa diacylglicerol (DAG) dan ceramide. ${ }^{(4)}$ Hal ini mengakibatkan pembentukan ATP berkurang dari bahan dasar glukosa, sehingga sumber asetil-CoA dapat berasal dari hasil pemecahan asam lemak jenuh, atau sumber energi dialihkan ke bahan lemak. Disamping itu USFA menghambat proses lipogenesis, keadaan ini dapat memicu terjadinya peninggian lemak darah.

Asam palmitat dan oleic acid dalam tubuh berguna sebagai sumber energi melalui oksidasi asam lemak pada posisi $\beta$. Oleic acid dapat menghambat signal transduction insulin pada sel hepar. ${ }^{(5)}$ Apabila jumlah lemak berlebih dari kebutuhan, maka senyawa lem akan ini disimpan sebagai trigliserida dalam jaringan adiposa. Penyimpanan $\mathrm{TG}$ yang berlebihan menyebabkan sel adiposit hypertrophy dan hyperplasi atau menimbulkan obesitas. ${ }^{(6)}$ Keadaan ini akan memicu pembentukan TNF- $\alpha$ yang bersifat inflamasi dan menghambat sekresin insulin. ${ }^{(7,8)}$ Palmitat dan oleat merupakan senyawa penghambat kuat terhadap sekresi insulin. $^{(9)}$

Makropag mudah keluar dari sel adiposit yang mengalami hypertropi (10). Selanjutnya terjadi peningkatan (TNF- $\alpha$ ) dan interleukin-6 (IL-6) dalam darah. ${ }^{(8,11)}$ TNF- $\alpha$ dapat meningkatkan free fatty acid (FFA) darah melalui lipolisis. Sekresi insulin melalui unpan balik glukosa darah (glucose stimulating insulin secretion (GSIS) akan berkurang bila terdapat peninggian IL-6, sebaliknya terjadi peninggian Nonesterified FA (NEFA), kedua keadaan ini akan menurunkan aktivitas insulin. $^{(12-14)}$ 
Obesitas sering berlanjut menjadi resistensi insulin dan akhirnya menderita diabetes mellitus type 2 (DM2). Jumlah penderita DM2 dari tahun ke tahun terus meningkat, penderita DM2 di Indonesia khususnya dilaporkan sebanyak 17 juta orang $(8,6$ persen dari jumlah penduduk) dimana Indonesia berada pada urutan ke 4 terbanyak menderita DM2 di dunia, angka ini akan meningkat terus bahkan pada 2030 diperkirakan penderita DM2 dunia mencapai 366 juta.

Pada penelitian ini akan dilihat perbedaan pengaruh diet tinggi minyak sawit segar (DMS) dan diet tinggi minyak sawit jelantah (DMSJ) terhadap profil lemak darah dan senyawa proinflamasi TNF- $\alpha$. Diharapkan penelitian ini dapat dijadikan pedoman bagi para ilmuwan atau masyarakat bagaimana akibat pemakaian minyk sawit yang berlebihan terhadap kesehatan.

\section{Metode Penelitian}

Penelitian merupakan penelitian experimental di laboratorium. Pemeliharaan dan perlakuan binatang percobaan dilaksanakan pada laboratorium binatang Farmasi UNAND dan pemeriksaan kimia darah trigliserida dan fraksi lemak lain dilakukan pada lab. Biokimia FK Unand.

Sampel pada penilitian ini adalah tikus galur Wistar yang sudah tersedia pada Laboratorium Farmasi Unand. Karakteristik sampel adalah tikus jantan, tidak sakit dan umur \pm 2 bulan dengan berat antara 200-250 gram. Perkiraan besar sampel minimal dihitung dengan menggunakan rumus Fraenkle and Wallen, dimana jumlah tiap kelompok adalah 5 ekor. Sampel terdiri dari tiga kelompok yaitu kelompok kontrol negatif (KN), kontrol positif (KP) dan kontrol perlakuan dengan minyak (DMS).

Diet tinggi lemak minyak sawit disesuaikan dengan penelitian Flanagan yaitu $24.3 \%$ carbohydrate; $52.8 \%$ fat; $22.9 \%$ protein. ${ }^{(15)}$ Pada penelitian ini diet tinggi minyak sawit (DMS) dengan cara menambahkan minyak sawit segar 50\% dari berat makanan standar dan diet tinggi minyak jelantah minyak sawit (DMSJ) dengan cara menambahkan minyak sawit jelantah 50\% dari berat makanan standar. Penelitan dilakukan selama 8 minggu dimana kontrol negatif $(\mathrm{KN})$ diberi diet standar $\pm 7 \mathrm{gr} /$ hari, kontrol positif (KP) diberi diet standar adlibitum. Kelompok DMS dan DMSJ juga diberikan diet secara adlibitum.

Variabel yang diteliti adalah lemak darah berupa; Trigliserida, kolesterol total, HDL-kol, non HDLKol, rasio kolesterol total dengan HDL-kol dan TNF- $\alpha$. Pemeriksaan lemak darah dengan spectrophotometer dan serum tikus diambil setelah puasa \pm 8 jam. Darah diambil melalui vena porta dan sebelumnya dianastesi dengan dietyleter.

\section{HASIL PENELITIAN}

Tikus pada penelitian ini terdiri dari tiga kelompok, masing-masing kelompok dilakukan penelitian selama 8 minggu. Tiap kelompok tikus diberikan perlakuan yang berbeda seperti tabel berikut 
Tabel 1. Gambaran Perlakuan Terhadap Tikus Percobaan

\begin{tabular}{lllll}
\hline Kelompok & N & Tikus & Diet & Kode \\
\hline A & 5 & Kontrol negatif & Standart : 6-7 gr /hari & KN \\
B & 5 & Kontrol positif & Standart : adlibitum & KP \\
C & 5 & Diet tinggi minyak Sawit & Standart + 50\% MS & DMS \\
D & 5 & $\begin{array}{l}\text { Diet Tinggi minyak sawit } \\
\text { jelantah }\end{array}$ & Standart + 50\% MS & DMSJ \\
\hline
\end{tabular}

Setelah dilakukan observasi dan pengumpulan data terhadap masing-masing kelompok didapatkan hasil sebagai berikut

Tabel 2. Gambaran Berat Badan Tikus (gr) Kontrol Positif Sebelum dan Sesudah Perlakuan

\begin{tabular}{lllllll}
\hline BB & N & Minimum & Maximum & Mean & $\begin{array}{l}\text { Std. } \\
\text { Deviation }\end{array}$ & Selisih BB \\
\hline Awal & 5 & 164.00 & 181.00 & 172.83 & 6.79 & $53,17 \mathrm{gr}$ \\
Akhir & 5 & 201.00 & 258.00 & 226.00 & 23.75 & $30,4 \%$ \\
\hline
\end{tabular}

Tabel 3. Gambaran Berat Badan (gr) Tikus Sebelum dan Sesudah Perlakuan DMSJ

\begin{tabular}{lllllll}
\hline BB & N & Minimum & Maximum & Mean & $\begin{array}{l}\text { Std. } \\
\text { Deviation }\end{array}$ & Selisih BB \\
\hline Awal & 5 & 151.00 & 162.00 & 156.60 & 4.28 & 67 gr \\
Akhir & 5 & 214.00 & 236.00 & 223.60 & 10.7 & $43 \%$ \\
\hline
\end{tabular}

Kelompok KP mendapat makanan standar secara adlibitum sehingga BB meningkat sebanyak $30,4 \%$

Tabel 4. Gambaran Berat Badan (gr) Tikus sebelum dan sesuadah perlakuan DMS

\begin{tabular}{lllllll}
\hline & & & & & Std. & Selisih BB \\
& N & Minimum & Maximum & Mean & Deviation & \\
\hline Awal & 6 & 191.00 & 200.00 & 196.16 & 3.710 & 127.34 \\
Akhir & 6 & 318.00 & 327.00 & 323.50 & 3.674 & $65 \%$ \\
\hline
\end{tabular}

Penambahan berat badan tikus dengan DMS lebih banyak dibandingkan dengan penambahan $\mathrm{BB}$ tikus kontrol yaitu $65 \%$, berbeda signifikan dengan KP yaitu $\mathrm{p}<0.05$, begitu juga kenaikan BB DMSJ. 
Tabel 5. Gambaran Trigliserida Darah Tikus Setelah Perlakuan

\begin{tabular}{llllll}
\hline Trigliserida & N & Minimum & Maximum & Mean & $\begin{array}{l}\text { Std. } \\
\text { Deviation }\end{array}$ \\
\hline KP & 6 & 44.00 & 119.00 & 84.83 & 26.20 \\
DMS & 5 & 54.00 & 160.00 & 98.40 & 38.88 \\
DMSJ & 5 & 103.00 & 146.00 & 119.00 & 16.54 \\
\hline
\end{tabular}

Kadar trigliserida kelompok KP,DMS dan DMSJ lebih tinggi dari KN dengan masing-masing nilai $\mathrm{p}<0,05$ atau $(\mathrm{p}=0,008)$

Tabel 6. Gambaran TNF- $\alpha$ Darah Tikus Setelah Perlakuan

\begin{tabular}{llllll}
\hline TNF-alfa & N & Minimum & Maximum & Mean & $\begin{array}{l}\text { Std. } \\
\text { Deviation }\end{array}$ \\
\hline KN & 5 & 180.83 & 208.06 & 193.78 & 9.70 \\
KP & 5 & 33.12 & 312.64 & 139.74 & 115.71 \\
DMS & 5 & 108.93 & 478.21 & 249.53 & 166.96 \\
DMSJ & 5 & 727.67 & 1176.47 & 972.77 & 195.86 \\
\hline
\end{tabular}

Kadar TNF- $\alpha$ darah tikus DMS lebih tinggi dari TNF- $\alpha$ KN bermakna $p<0,05$ $(\mathrm{p}=0,04)$ sedangkan kadar TNF- $\alpha$ tikus dengan perlakuan DMSJ jauh lebih tinggi dari kontrol bermakna $\mathrm{p}<0,05(\mathrm{p}=0,08)$ begitu juga dengan TNF $-\alpha$ DMS $\mathrm{p}<0,05 .(\mathrm{p}=0,08)$

Tabel 7. Gambaran Kolesterol Total (mg/\%)Darah Tikus Setelah Perlakuan

\begin{tabular}{llllll}
\hline Kolesterol total & N & Minimum & Maximum & Mean & $\begin{array}{l}\text { Std. } \\
\text { Deviation }\end{array}$ \\
\hline KN & 5 & 25.08 & 39.98 & 33.24 & 6.09 \\
KP & 5 & 54.00 & 72.00 & 60.20 & 6.87 \\
DMS & 5 & 46.00 & 65.00 & 54.80 & 8.29 \\
DMSJ & 5 & 58.00 & 85.00 & 68.80 & 10.18 \\
\hline
\end{tabular}

Kadar kolesterol total darah tikus perlakuan DMS lebih tinggi bermakna $\mathrm{p}=0,008$ dari kolesterol darah $\mathrm{KN}$ tetapi lebih rendah $\mathrm{p}=0,167$ dari KP. Kadar koleasterol DMSJ paling tinggi dari semua kelompok tetapi peninggian bermakna hanya dengan $\mathrm{KN} \mathrm{p}=0,008$.

Tabel 8. Gambaran HDL- Kolesterol (mg\%)Darah Tikus Setelah Perlakuan

\begin{tabular}{llllll}
\hline HDL-Kolesterol & N & Minimum & Maximum & Mean & $\begin{array}{l}\text { Std. } \\
\text { Deviation }\end{array}$ \\
\hline KN & 5 & 16.00 & 30.00 & 24.00 & 5.83 \\
KP & 5 & 17.32 & 47.31 & 29.71 & 11.59 \\
DMS & 5 & 17.03 & 29.02 & 21.57 & 4.76 \\
DMSJ & 5 & 21.94 & 49.20 & 31.93 & 11.34 \\
\hline
\end{tabular}


Kadar HDL-kolesterol darah tikus DMS lebih rendah dari kolesterol darah KN $(\mathrm{p}=0,833)$. Kadar HDL- kolesterol darah tikus DMSJ lebih tinggi dari KN juga tidak bermakna $\mathrm{p}=0,643$.

Tabel 9. Gambaran Non-HDL- Kolesterol Darah (mg\%) Tikus Setelah Perlakuan

\begin{tabular}{llllll}
\hline Non-HDL Kol & N & Minimum & Maximum & Mean & $\begin{array}{l}\text { Std. } \\
\text { Deviation }\end{array}$ \\
\hline KN & 5 & 8.36 & 9.98 & 9.24 & 0.70 \\
KP & 5 & 24.69 & 40.68 & 30.49 & 6.38 \\
DMS & 5 & 28.74 & 46.48 & 33.23 & 7.614 \\
DMSJ & 5 & 33.20 & 41.06 & 36.06 & 2.96 \\
\hline
\end{tabular}

Kadar non HDL-Kolesterol darah tikus paling tinggi adalah DMSJ berbeda signifikan dengan $\mathrm{KN}$, diikuti oleh DMS dan KP dimana keduanya meningkat bermakna $(\mathrm{p}=0,008)$

Tabel 10. Gambaran Rasio Total Kolesterol/HDL-Kolesterol Darah Tikus Setelah Perlakuan

\begin{tabular}{llllll}
\hline $\begin{array}{l}\text { Rasio } \\
\text { Kol Tot/HDL }\end{array}$ & N & Minimum & Maximum & Mean & $\begin{array}{l}\text { Std. } \\
\text { Deviation }\end{array}$ \\
\hline KN & 5 & 1.30 & 1.57 & 1.40 & 0.11 \\
KP & 5 & 1.52 & 3.35 & 2.23 & 0.72 \\
DMS & 5 & 2.14 & 3.51 & 2.60 & 0.55 \\
DMSJ & 5 & 1.73 & 2.87 & 2.25 & 0.47 \\
\hline
\end{tabular}

Rasio Kolesterol total dengan HDL-Kol paling tinggi adalah DMS berbeda signifikan dengan $\mathrm{KN}(\mathrm{p}=0,008)$ diikuti oleh DMSJ ( $\mathrm{p}=0,008)$ sedangkan perbedaan peninggian DMS, DMSJ dengan KP tidak bermakna $(\mathrm{p}=0,992)$.

\section{Diskusi}

Penambahan berat badan tikus yang signifikan kelompok DMS dan DMSJ dibandingkan dengan KP kemungkinan karena penambahan MS dan MJ pada diet standar. Diet tinggi MS dan MJ yang diberikan pada tikus percobaan ini sudah melebihi kebutuhan tikus percobaan, hal ini sesuai dengan pertambahan BB tikus.

Kadar TG darah DMSJ meningkat 6,6 kali dari $\mathrm{KN}$ sedangkan kenaikan BB kelompok KP hanya 4,7 kali $\mathrm{KN}$ dan peninggian kelompok DMS 5,5 kali KN. USFA kelompok DSMJ sebahagian besar sudah dirubah menjadi SFA karena proses oksidasi sehingga peran USFA pada DSMJ sudah berkurang.

TNF- $\alpha$ darah meningkat signifikan pada kelompok DMS dan DMSJ dibandingkan dengan kelompok $\mathrm{KN}$ dan $\mathrm{KP}$, walaupun kadar TG kelompok KP meningkat tetapi tidak diikuti peninggian TNF- $\alpha$. Hal ini mungkin disebabkan peninggian TG kelompok KP tidak diikuti dengan hypertropi atau hyperplasi adiposa sehingga tidak memicu makropag.

Kadar kolesterol darah total kelompok DMS lebih rendah dari KP tetapi lebih tinggi bermakna dari $\mathrm{KN}$. Hal ini menunjukkan peninggian 
kolesterol DMS mungkin pengaruh USFA pada minyak sawit. Berbeda dengan kelompok DMSJ kolesterol total meningkat dari $\mathrm{KP}$, hal ini mungkin disebabkan oleh berkurangnya jumlah USFA pada DMSJ karena oksidasi saat penggorengan. Kadar HDL-Kol semua kelompok berbeda tapi tidak bermakna, mungkin disebabkan protein fraksi lemak ini sama yaitu berasal dari makanan standar. Non HDL kol pada kelompok KP,DMS dan DMSJ meningkat bermakna bila dibandingkan dengan $\mathrm{KN}$, tetapi kadar non-HDl Kol ketiga kelompok diatas berbeda tapi tidak signifikan. Hal ini sesuai dengan peningkatan TG pada ketiga kelompok tersebut. Keadaan ini juga terlihat pada rasio Kol total/HDLKol yaitu terjadi peningkatan tapi tidak bermakna.

\section{Kesimpulan}

Diet tinggi minyak sawit meningkatkan trigliserida darah tikus, peningkatan oleh DMSJ lebih tinggi bermakna dibanding DMS dan hal ini diikuti oleh peninggian senywa proinflamasi dimana peninggian TNF$\alpha$ akibat DMSJ lebih tinggi bermakna dibandingkan dengan peninggian oleh DMS. Profil lemak darah ; kolesterol total, HDL-Kol, Non HDl-Kol dan rasio Kol.Tot/HDL-Kol pada umumnya meningkat bermakna.

Untuk menjaga profil lemak darah dalam batas normal dan mencegah pembentukan senyawa pro inflamasi hendaklah menghindari komsumsi minyak sawit yang berlebihan dari kebutuhan tubuh. Menghindari komsumsi minyak sawit yang sudah digoreng berulang kali sebab minyak jenis ini lebih banyak meningkatkan lemak darah dan senyawa proinflamasi dari minyak sawit segar.

\section{KEPUSTAKAAN}

1. Bansal G., W. Zhou, T.-W. Tan, F.-L. Neo, H.-L. Lo, Analysis of trans fatty acids in deep frying oils by three different approaches Food Chemistry 116, 535-41 (2009).

2. Robinson L., Trans Fatty Acids Trends in Food Science \& Technology 20, 182- (2009).

3. Wijendran V., A. Pronczuk, C. Bertoli, K.C. Hayes, Dietary trans-18:1 raises plasma triglycerides and VLDL cholesterol when replacing either 16:0 or 18:0 in gerbils The Journal of Nutritional Biochemistry 14, 584-90 (2003).

4. Ragheb R., A.M. Medhat, G.M.L. Shanab, D.M. Seoudi, I.G. Fantus, Links between enhanced fatty acid flux, protein kinase $\mathrm{C}$ and NF[kappa]B activation, and apoB-lipoprotein production in the fructose-fed hamster model of insulin resistance Biochemical and Biophysical Research Communications 370, 134-9 (2008).

5. Kim K., H.Y. Kim, E.J. Son, J. Heo, J. Cheong, Oleic acid inhibits hepatic insulin signaling through deregulation of STAT3 activation and C/EBP[alpha] expression Cellular Signalling 21, 126976 (2009).

6. Milanski M., G. Degasperi, A. Coope, J. Morari, R. Denis, D.E. Cintra, D.M.L. Tsukumo, et al., Saturated Fatty Acids 
Produce an Inflammatory Response Predominantly through the Activation of TLR4 Signaling in Hypothalamus: Implications for the Pathogenesis of Obesity J. Neurosci. 29, 359-70 (2009).

7. HOTAMISLIGIL G.K.S., D.L. MURRAY, L.N. CHOY, B.M. SPIEGELMAN, Tumor necrosis factor a inhibits signaling from the insulin receptor Biochemlstry 91, 4854-8 (1994).

8. Borst S.E., C.F. Conover, High-fat diet induces increased tissue expression of TNF[alpha] Life Sciences 77, 215665 (2005).

9. Roduit R., J. Morin, F. Masse, L. Segall, E. Roche, C.B. Newgard, F. AssimacopoulosJeannet, et al., Glucose Downregulates the Expression of the Peroxisome Proliferatoractivated Receptor-alpha Gene in the Pancreatic beta -Cell $J$. Biol. Chem. 275, 35799-806 (2000).

10. Cawthorn W.P., J.K. Sethi, TNF-[alpha] and adipocyte biology FEBS Letters 582, 117-31 (2008).
11. Håversen L., K.N. Danielsson, L. Fogelstrand, O. Wiklund, Induction of proinflammatory cytokines by long-chain saturated fatty acids in human macrophages Atherosclerosis 202, 382-93 (2009).

12. Guilherme A., J.V. Virbasius, V. Puri, M.P. Czech, Adipocyte dysfunctions linking obesity to insulin resistance and type 2 diabetes Molecular cell biology 9, 367-77 (2008).

13. Bouzakri K., P. Plomgaard, R. Krogh-Madsen, B.K. Pedersen, J. Zierath, P025 - TNF-alpha induces skeletal muscle insulin resistance in healthy human subjects via inhibition of AS160 phosphorylation Annales d'Endocrinologie 66, 415- (2005).

14. Moller D.E., Potential Role of TNF-[alpha] in the Pathogenesis of Insulin Resistance and Type 2 Diabetes Trends in Endocrinology and Metabolism 11, 212-7 (2000).

15. Flanagan A.M., J.L. Brown, C.A. Santiago, P.Y. Aad, L.J. Spicer, M.T. Spicer, High-fat diets promote insulin resistance through cytokine gene expression in growing female rats The Journal of Nutritional Biochemistry 19, 505-13 (2008). 